\title{
Workaholism Research on Junior Administrative Police Officers in the Police Department
}

\author{
Mustafa ZINCIRKIRAN \\ Dicle University, Health Care Management, Faculty of Economics and Administrative \\ Sciences, Diyarbakır, Turkey \\ Email: mustafa.zincirkiran@dicle.edu.tr
}

DOI: $\quad 10.6007 /$ IJARBSS/v4-i3/727 URL: http://dx.doi.org/10.6007/IJARBSS/v4-i3/727

\begin{abstract}
This research aims to determine whether commissioners and deputy commissioners, who are junior administrative police officers in the police department, are workaholic or not. The research also aims to test validity and reliability of the two-dimension workaholism scale, which was previously applied in our country in relation to workaholism.

There were not enough findings to identify police managers as workaholic in the end of the research. However, the result obtained reveals a hidden workaholism in the organization. Even if the item ranking obtained in the factor analysis held in scope of the research was different, validity and reliability of "Workaholism Scale Turkish Form" was accepted. A number of suggestions regarding workaholic employees were made to the managers on the basis of findings in the end of the research.
\end{abstract}

Keywords: Workaholism, Factor Analysis, Junior Administrative Officer, Police, Police Department

JEL CODES: M10, E32, M1, H00

\section{Introduction}

Professional life has a great significant for individuals to maintain their lives and attain a place within the society. In this regard, work or job provides many advantages such as developing an identity, using one's potential, self-realization, self-esteem, social support, financial earnings, spending time. Besides these advantages, there are also certain problems that may arise in the professional life. These problems may be of a personal and psychological origin or be caused by the organization, management or the work.

There are many problems in the individuals' professional life gaining more and more importance in today's societies, which influence both their professional lives and family lives. Job stress, extremely busy pace of work, fatigue, burnout, psychological disorders arising from job stress may be given as examples. The constantly developing technology, intensive competition in international economies, the competition of taking market share among enterprises and the arising sense of individual competition bring to the employees different viewpoints or opinions about the professional life. 
Professional lives of all individuals in the society makes certain positive or negative impacts on the other areas of life. The profession of policing is one of these areas. Various researches have been made on the police till the present. Policemen's work-family life balance, burnout, professional satisfaction, emotional intelligence and leadership are some of the subjects researched (Azizoğlu and Özyer, 2010; Kaya 2010; Delice and Günbeyi 2013; Şişman and Topgül 2013; Tiftik 2014). This research has been carried out in order to determine whether of the policemen serving in an intense work pressure in our country are workaholic or not.

\section{Literature on Work holism}

It would be better to discuss the meaning of the word "workaholic", rather than the concept of workaholism. "Workaholic" having taken its place in the current dictionary of Turkish Language Society means a person who is addicted to and loves his job. This concept is derived by adding the appendix "holic", which takes place in the end of the word alcoholic generally used for alcohol addicts, and used in our language for the concepts of "absenteeism" or "presenteeism" in English, which are defined in detail below.

To define this concept, the term "workaholic" is used instead of presenteeism in English. Although there are slight differences between these two concepts, they mean the same thing: work and work-related activities of an individual take precedence over the other vital activities and affairs and the working environment becomes irreplaceable (Porter 1996: 75).

Spence and Robbins describe workaholic people as "individuals who are highly addicted to their work, motivated about their work in order to reduce intrinsic stresses and have low level of fun with their work" in comparison to other individuals (Douglas and Morris 2006: 395).

The concept of workaholism was firstly used by Oates in 1968. Oates defines workaholism as "an excessive and uncontrollable need for working constantly in a way to adversely influence emotions, health, happiness or relationship with others as a result of this non-stop and continuous mode of working" (McMillan et al. 2001: 69).

The term "workaholic" was used for the first time in academic studies by Spence and Robbins (Seybold and Salomone 1994: 6).

In the view of Spence and Robbins, workaholism is a mode of behavior of individuals who are excessively addicted and committed to working and cannot mentally break away from their work even if they are not at work and therefore stay away from other aspects of live which are not related to work (Spence and Robbins 1992:161).

Workaholism may be described as an individual's constantly feeling a need to work and feel uncomfortable when not working. In this regard, the point in workaholism is excessive and unnecessary work and focus on work. Workaholic individuals may neglect their private live, family and relatives, hobbies and intellectual activities (Yöney 2005).

More comprehensive studies were carried out on the concept of workaholism in the following years. Burke suggests that workaholic people are more enthusiastic and selfsacrificing about overworking when compared to other typical employees. According to Burke, 
workaholic people feel themselves more insecure than their co-workers and therefore they are in need of being praised and approved (Burke 2000: 13).

Some researchers draw a parallel between workaholic and alcoholic in the lexical sense. In this respect, it is a special point of interest and research for researches. Although there is a kind of addiction in both cases, workaholism is a state easily approved and accepted by the society. There are even many expressions of appreciation for workaholism in the literature such as "working day and night, living and breathing with work" (Zincirkıran 2013: 9).

Workaholism is a situation realized when the individual starts to work. There are different concepts to define an individual's excessive desire of working on any matter outside the professional life. In this sense, workaholism may be described as an individual's being overly attached to the working life and "being married to the work" with an attitude of not enjoying activities other than work, taking work home, constantly focusing on work or adopting a similar approach.

Many researches have been made on workaholism in recent years. It is seen in these researches that the concept is associated with many concepts like burnout, work-life balance, gender, divorce, organizational commitment, work-family conflicts etc. Among these researches, the ones recently carried out are assessed below.

In the research of Dewilde et al. (2007) held with the participation of 2759 Belgian fulltime workers about the impact of individual and organizational history of workaholism on the employees, it is concluded that there is a relation between workaholism and organizational and individual performances of workers.

In the research of Schaufeli et al. (2008) held with the participation of 854 mid-level managers about the relation between workaholism, burnout and work responsibility, it is found that there is a positive correlation between workaholism and burnout.

In the research of Burke et al. (2007) held with the participation of 406 Turkish Professors in order to examine the relation between the extra work satisfaction and psychological satisfaction, scale of $S \& R$ is not approved and the results are similar to the research carried out in the North America. Furthermore, it is concluded that cultural factors influence the results obtained.

In the study of Aziz and Cunningham (2008) held with the participation of 199 full-time workers about the relation between the role of gender in workaholism, job stress and work-life imbalance, it is concluded that there is a positive correlation between workaholism and gender, but workaholism is not directly related to job stress and work-life imbalance.

In the study of Chamberlin and Zhang (2009) held with the participation of 347 university students about the relation between workaholism, health and self-confidence, it is determined that there is a meaningful relation between workaholic parents of students and their own workaholism. Workaholism is also related to health and self-confidence. It is concluded that students with workaholic parents have more psychological health problems, less self-confidence and more physical health problems.

In the research of Bayraktaroğlu et al. (2009) held with 319 participants working in the banking sector in order to examine the relation between workaholism and organizational commitment, it is determined that there are positive and meaningful relations between the sense of work enjoyment and work drive and emotional and normative commitment, which are kinds of organizational commitment. It is also concluded that there is a meaningful relation 
between the work drive and commitment of attendance. However, the findings obtained in the research are not enough for defining the participants as workaholic individuals.

Results of Huang et al.'s (2010) research held with the participation of 1235 full-time Taiwanese workers about the psychometric properties of the Chinese version of workaholism scale include findings that support the previous studies in this area.

In the research of Akın and Oğuz (2010) held with the participation of 227 teachers in order to determine the relations between the workaholism tendencies and burnout levels, it is concluded that workaholism tendency does not differ with gender and educational background, but differs with age.

Doğan and Tel (2011) made a research on employees from different occupational groups in order to adapt DUWAS (Dutch Work Addiction Scale), which was created by Schaufeli, Taris and Bakker (2006), to Turkish and test its reliability and validity. It is concluded in the research that Turkish form of DUWAS-TR is a valid and reliability instrument of measurement that may be used for measuring workaholism.

In the study of Emhan et al. (2012) held with the participation of 170 independent accountants and financial advisors in order to examine the relation between workaholism and obsession for public and private sector employees, the findings obtained were not enough for defining the participants as workaholic. It is determined that there is a linear relationship between "work enjoyment", "contemplation", "control" and "certainty levels".

In the research of Bashan (2012) held with the participation of 348 administrative personnel working in the automotive sector about the relation between workaholism and burnout, it is concluded that there is a positive relation between workaholism and burnout and burnout is influenced by workaholism.

According to the results of the research of Bardakçı and Baloğlu (2012) on school managers, workaholism tendencies of school managers do not differ with gender, institution, educational background, branch, marital status or duty, but differ with age, seniority, time spent at work in a day, frequency of taking work home in a month and working in weekends. It is also suggested that school managers, who work more than fifty hours a week, take work home five times or more in a month and work five hours or more in weekends, may be identified as workaholic.

\section{RESEARCH METHOD}

\subsection{Purpose of the Research}

This research aims to determine whether junior managers in the police department (commissioners and deputy commissioners), who are assumed to act in a workaholic manner, are workaholic or not. The research also aims to test validity and reliability of the twodimension workaholism scale, which was adapted to Turkish in consequence of the research of Kart (2005).

\subsection{Data Collection Method}

The research was applied on a total of 189 mid-level police managers in different branches and provinces of Turkey in 2012. WorkBAT (Working Battery) scale, which was developed by Spence and Robbins (1992) and used in many researches, was used in the 
research as workaholism scale. Croncbach Alpha $(\alpha)$, indicating the coefficient of internal consistency, was found as 0.67 . This result proves that the scale is reliable. Turkish Form of the scale consisting of two sub-dimensions, which was adapted by Kart (2005) and validity and reliability of which was ensured, was used in the research. These sub-dimensions are Work Enjoyment (WE) and Drive (D). The scale consists of 20 statements, out of which 18 are positive and 2 are negative, in 2 sub-dimensions. There are 10 questions in the category of Work Enjoyment and 10 questions in the category of Work Drive. There is a list of preference in the form of 5-point Likert containing the statements "Strongly Agree", "Agree", "Neither Agree Nor Disagree", "Disagree", "Strongly Disagree". Answers to the statements are graded with points 5-4-3-2-1 from "Strongly Agree" to "Strongly Disagree".

\subsection{Data Analysis}

Data obtained from the questionnaire applied in the research are transferred to the electronic environment and analyzed by means of SPSS 16.0 package software. Cronbach Alpha value was calculated as 0.67 in the reliability test conducted in order to determine the reliability and validity of the data, which means the data are reliable enough. The first requirement for a questionnaire to be valid is its being reliable. Therefore, the upper limit for validity is equal to the square root of the reliability coefficient. Therefore, validity value would be $\mathbf{v} 0.67=0.81$. Reliability may bring an upper limit for validity; however, it never guarantees validity (Karagöz et al. 2010:10).

Firstly, the frequencies and percentages of the data obtained in the questionnaire conducted to the participants were calculated. Then, factor analysis was carried out on the 20-item scale applied for workaholism and 2 factors were determined.

\section{FINDINGS AND DISCUSSION}

\subsection{Descriptive Findings}

Table 1. Demographic Characteristics of Samples.

\begin{tabular}{|c|c|c|}
\hline Demographic Characteristic & Value & Number \\
\hline \multicolumn{3}{|l|}{ Description of the line item } \\
\hline Month and year of survey & \multicolumn{2}{|c|}{ March-April 2012} \\
\hline Sample size & \multicolumn{2}{|c|}{189} \\
\hline \multicolumn{3}{|l|}{ Gender } \\
\hline Female & $3.2 \%$ & 6 \\
\hline Male & $96.8 \%$ & 183 \\
\hline \multicolumn{3}{|l|}{ Age } \\
\hline $20-30$ & $50.8 \%$ & 96 \\
\hline $31-40$ & $49.2 \%$ & 93 \\
\hline \multicolumn{3}{|l|}{ Marital Status } \\
\hline Married & $90.5 \%$ & 171 \\
\hline Single & $9.5 \%$ & 18 \\
\hline Income Level & & \\
\hline
\end{tabular}


1100-2000TL

TL 2100-3000

3100 and over

Work Experience

6-10 years

11-15 years

$16-20$ years
$2.1 \% \quad 4$

$91 \% \quad 172$

$6.9 \% \quad 13$

$83.6 \% \quad 158$

$14.8 \% \quad 28$

$1.6 \% \quad 3$.

The research was carried out in March and April, 2012. Out of 189 police managers having participated in the research, $6(3.2 \%)$ are women and $183(96.8 \%)$ are men. $96(50.8 \%)$ of participants are within the age range of $20-30$ and 93 (40.2\%) within 31-40. 171 (90.5\%) of participants are married and $18(9.5 \%)$ are single. $4(2.1 \%)$ of the participants have an income of TL 1100-2000, 172 (91\%) have an income of TL 2100-3000 and 13 (6.9\%) have an income over TL 3000. In terms of work experience, it is determined that 158 (83.6\%) of the participants are on duty for $6-10$ years, 28 (14.8\%) for $11-15$ years and $3(1.6 \%)$ for more than 15 years.

Factor loads and Eigen values obtained in the factor analysis in relation to the factorial dimensions are indicated in the following table. Eigen value indicates the ratio of betweengroup sum of squares to the in-group sum of squares. The obtained matrix was analyzed by means of principle component analysis. Each element of matrices formed in the factor analysis are the factor weights indicating the correlation between each variable and each factor.

The factor analysis conducted should also be evaluated through Kaiser-Mayer-Olkin (KMO) test. In KMO test, the values equal to or over 0.5 mean that the sample as measurement insufficiency and factors may be analyzed. Similarly, the most important degree should be lower than 0.05 in Barlett test (Hutcheson and Sofroniou 1999).

In the following Table 2, average, standard deviation and factor loads of 2 factors are given.

Table 2. Rotated Component Matrix.

\begin{tabular}{lcccc}
\hline Component & $\mathbf{X}$ & $\mathbf{S}$ & $\mathbf{1}$ & $\mathbf{2}$ \\
\hline Fact. 1 & & & & \\
VAR0002 & 2.5397 & 1.07919 & 0.397 & \\
VAR0003 & 2.4339 & 1.18147 & 0.701 & \\
VAR0004 & 2,5026 & 1.23178 & 0.687 & \\
VAR0006 & 3.0476 & 1.19967 & 0.675 & \\
VAR0007 & 3.2804 & 1.06725 & 0.661 & \\
VAR0008 & 2.5767 & 1.04204 & -0.249 & \\
VAR0009 & 2.7196 & 1.10641 & -0.146 & \\
VAR00012 & 2.8942 & 1.12487 & 0.617 & \\
VAR00019 & 3.1376 & 1.25990 & 0.385 & \\
VAR00020 & 3.2011 & 1.08265 & 0.466 &
\end{tabular}


Fact 2

$\begin{array}{llll}\text { VAR0001 } & 3.8307 & 1.02257 & 0.485 \\ \text { VAR0005 } & 2.7196 & 1.29676 & -0.406 \\ \text { VAR0005 } & 3.5714 & 0.99007 & 0.597 \\ \text { VAR00011 } & 3.5714 & 1,11156 & 0.542 \\ \text { VAR00011 } & 3.2646 & 1.14104 & 0.455 \\ \text { VAR00014 } & 3.6984 & 1.04629 & 0.656 \\ \text { VAR00015 } & 3.3492 & 1.12740 & 0.484 \\ \text { VAR00016 } & 3.2116 & 1.14282 & 0.188 \\ \text { VAR00017 } & 3.2910 & 1.05939 & 0.429 \\ \text { VAR00018 } & 3.4550 & 1.00760 & 0.525\end{array}$

Factor 1; factor loads range between 0.397 (item 2) and 0.466 (item 20). When rotation values are examined, it is seen that $15.395 \%$ of the total variance is disclosed. This indicates that more than half of the accumulation is in the factor 1 . Its eigenvalue 3.079. This factor may be called as "Work enjoyment", considering the contents of sub-items in Factor 1 and results of the previous researches.

Factor 2; factor loads range between 0.485 (item 1) and 0.525 (item 18). When rotation values are examined, it is seen that $14.496 \%$ of the total variance is disclosed. Its eigenvalue 2.899 . This factor may be called as "Work drive", considering the contents of sub-items in the factor.

Table 3. Total Variance Explained.

\begin{tabular}{crrrrrrr}
\hline & \multicolumn{2}{c}{$\begin{array}{c}\text { Initial } \\
\text { Eigenvalues }\end{array}$} & \multicolumn{4}{c}{$\begin{array}{c}\text { Rotation Sums of Squared } \\
\text { Loadings }\end{array}$} \\
\hline & & & & & $\%$ of & \\
Component & Total & Variance & Cumulative & & & Cumulative \\
\hline 1 & 3.608 & 18.039 & 18.039 & 3.079 & 15.395 & 15.395 \\
2 & 0.171 & 11.852 & 29.891 & 2.896 & 14.496 & 29.891 \\
3. & 1.918 & 9.588 & 39.478 & & & \\
4 & 1.405 & 7.023 & 46.501 & & & \\
5. & 1.090 & 5.596 & 52.098 & & & \\
6 & 1.001 & 5.006 & 57.104 & & & \\
7 & 0.909 & 4.546 & 61.650 & & & \\
8 & 0.869 & 4.346 & 65.995 & & & \\
9 & 0.828 & 4.138 & 70.133 & & & \\
10 & 0.777 & 3.884 & 74.017 & & & \\
11 & 0.684 & 3.418 & 77.435 & & & \\
12 & 0.666 & 3.329 & 80.763 & & & \\
13 & 0.666 & 3.313 & 84.076 & & &
\end{tabular}




$\begin{array}{rrrr}14 & 0.562 & 2.809 & 86.885 \\ 15 & 0.528 & 2.639 & 89.524 \\ 16 & 0.499 & 2.495 & 92.019 \\ 17 & 0.453 & 2.263 & 94.281 \\ 18 & 0.453 & 2.064 & 96.345 \\ 19 & 0.387 & 1.937 & 98.282 \\ 20 & 0.344 & 1.718 & 100.000\end{array}$

In the Table 3 above, the eigenvalues of items related to workaholism are indicated. Eigenvalues are found in two factors, which are bigger than 1 . The first factor explains $15 \%$ of the variance, while the second factor explains 14\% thereof. 2 factors disclose half of the total variance (29.9\%). This result is consistent with the result of a previous research (Kart, 2005). However, there is a point to be taken into consideration. The item sequence obtained in the research is different from the item sequence in the factory analysis in the research carried out by Kart in 2005 . Therefore, factor names are replaced.

Table 4. KMO and Barlett's Test.

\begin{tabular}{|c|c|c|}
\hline \multicolumn{2}{|c|}{ Kaiser-Meyer-Olkin Measure of Adequacy of Sample } & 0.744 \\
\hline \multicolumn{3}{|l|}{ Bartlett's Test of } \\
\hline \multirow[t]{3}{*}{ Sphericity } & Approx.. Chi-square & 763.683 \\
\hline & df & 190 \\
\hline & Sig. & 0.000 \\
\hline
\end{tabular}

As seen in the foregoing table 4, result of KMO test on the sufficiency of sample size was found to be $\mathbf{0 . 7 4 4}$. This result proves that the date may be used in the factor analysis (The result is good if it is in the range of 0.7-0.8, medium if in the range of 0.5-0.7 and it should be at least 0.5 ; if it is less than 0.5, more data should be collected). Barlett test specific correlation matrix is same with the identity matrix (all correlation coefficients are zero) and tests the null hypothesis. This test should be meaningful. Otherwise, there would be no relation between variables (Tonta, 2008: 30). Indeed, as seen in the table above, this value was found to be zero $(0.000)$ and therefore the result is considered meaningful. Considering all findings specified in the foregoing tables, it is possible to say that "Workaholism Scale Turkish Form" is valid and reliable.

Table 5. The Mean of the Participants' Answers to the Expressions

\section{Descriptive Statistics}

\begin{tabular}{lrrr}
\hline & & \multicolumn{2}{c}{ Std. } \\
& \multicolumn{3}{c}{ Deviatio } \\
2) I feel guilty when I take time off work. & Mean & $\mathbf{n}$ & $\mathbf{n}$ \\
& 2.539 & 1.07919 & 18 \\
3) My job is more like fun than work. & 7 & 9 & 9 \\
nat & 2.433 & 1.18147 & 18
\end{tabular}


4) My job is so interesting that it often does not seem like work.

6) I do more work than is expected of me strictly for the fun of it.

7) Most of the time, my job is very pleasurable.

8) I seldom find anything to enjoy about my work.

9) I feel obliged to work hard even when it is not enjoyable.

12) Sometimes when I get up in the morning, I can hardly wait to get to work.

19) I get bored and restless on vacations when I haven't anything productive to do.

20) I seem to have an inner compulsion to work hard.

1) I like my work more than most people do.

I really look forward to the weekend: all fun and no work!

10) I like to use my time constructively both on and off the job.

11) I lose track of time when I am involved in a project.

13) It is important to me to work hard even when I don't enjoy what I'm doing.

14) When I get involved in an interesting project, it's hard to describe how exhilarated I feel.

15) I often find myself thinking about work, even when I want to get away from it for a while.

16) Between my job and other activities I'm involved in, I don't have much free time.

17) I often feel that there is something inside me that drives me to work hard.

18) Sometimes I enjoy my work so much that I find a hard time stopping.

$\begin{array}{rlr}9 & & 9 \\ 2.502 & 1.23178 & 18 \\ 6 & & 9 \\ 3.047 & 1.19967 & 18 \\ 6 & & 9 \\ 3.280 & 1.06725 & 18 \\ 4 & & 9 \\ 2.576 & 1.04204 & 18 \\ 7 & & 9 \\ 2.719 & 1.10641 & 18 \\ 6 & & 9 \\ 2.894 & 1.12487 & 18 \\ 2 & & 9 \\ 3.137 & 1.25990 & 18 \\ 6 & & 9 \\ 3.201 & 1.08265 & 18 \\ 1 & & 9 \\ 3.830 & 1.02257 & 18 \\ 7 & & 9 \\ 2.719 & 1.29676 & 18 \\ 6 & & 9 \\ 3.571 & 0.99007 & 18 \\ 4 & & 9 \\ 3.571 & 1,11156 & 18 \\ 4 & & 9 \\ 3.264 & 1.14104 & 18 \\ 6 & & 9 \\ 3.698 & 1.04629 & 18 \\ 4 & & 9 \\ 3.349 & 1.12740 & 18 \\ 2 & & 9 \\ 3.211 & 1.14282 & 18 \\ 6 & & 9 \\ 3.291 & 1.05939 & 18 \\ 0 & & 9 \\ 3.455 & 1.00760 & 18 \\ 0 & & 9\end{array}$

In the Table 5, averages of participants' answers to the statements in the scale are given. For each statement in the scale, there is a preference list in 5-point Likert type containing the statements "Strongly Agree", "Agree", "Neither Agree nor Disagree", "Disagree" and "Strongly Disagree". Answers to the statements are graded with points 5-4-3-2-1 from "Strongly Agree" to "Strongly Disagree". The first ten statements, namely the factor 1, are named as "work enjoyment" and average of the answers is found to be 3.8333. According to this result, 
the findings are not sufficient for identifying police managers, composing the research population of our research, as "workaholic" in regard to the sub-dimension of work enjoyment. This result is consistent with the results of the researches carried out by Bayraktaroğlu et al., 2009, Emhan et al., 2009 and Zincirkıran, 2013 with different occupational groups. As the average of the factor 2 is $\mathbf{3 . 3 9 6 2}$, it is possible to assume a hidden workaholism with regard to the sub-dimension of work drive.

\section{CONCLUSION, EVALUATIONS AND SUGGESTIONS}

Findings obtained in the research carried out with the participation of 189 junior police managers in relation to workaholism suggest that there is a hidden workaholism in police managers with regard to the sub-dimension of work drive. However, no adequate finding is obtained to prove that there is a workaholism in different dimensions of the research. This result is in parallel with the results of other researches held with different occupational groups in our country. Even if the item ranking obtained in the factor analysis held in scope of the research is different, validity and reliability of "Workaholism Scale Turkish Form" is accepted.

However, this result does not mean that policemen or police managers are not or will not be workaholic. According to the study of Günbeyi and Gündoğdu published in 2010 with the title "Workaholic Employees of the Police Department", "It is requested from the personnel to serve with both their bodies and souls. Success of Turkish police department should be measured not with the length of time they have their personnel work, but with the efficiency of their employment. Furthermore, both the problem of workaholic employees and the problem of gangrened management will be solved when the managers are assessed by both their seniors and the personnel under their command." As stated here, policing is an occupation that may involve workaholic employees. According to Zincirkıran's (2013: 59) approach of workaholism, there are five different kinds of workaholism: occupational workaholism, characteristic workaholism, administrative workaholism, organizational workaholism and inherited workaholism. Different results may be obtained if more comprehensive researches are made on the occupation of policing, which is covered by occupational workaholism.

Scientists agree that workaholism is harmful in every aspect, has a negative impact on performance and leads to psychological problems between the employees. These researchers think that workaholism impairs the physical health of individuals and adversely influences their relationship with their families and colleagues (Machlowitz 1980: 43). From this perspective, the following suggestions are made for police managers and potential workaholic police officers;

$\checkmark$ It may be ensured that members of this profession work more regularly and efficiently by reviewing the working hours and work flows.

$\checkmark$ It may be ensured by means of new regulations that all managers and officers spend more time with their families. In this way, they may be kept away from workaholic behaviors.

$\checkmark$ Police managers in supervisory position in the police department should act in a constructive and regulatory manner towards the officers who are workaholic in their opinion and attempt to improve these officers. 
$\checkmark$ Managers should also take into account the fact that workaholism will damage the department in the medium and long term and take preventive measures. For example, trainings to prevent such harmful behaviors may be given through in-service training programs for members of the occupation.

$\checkmark$ The research should be carried out in different levels of the police department from managers to the officers. Considering the fact that officers work for a time longer than their managers, it may be suggested that officers have a higher potential to be workaholic.

To sum up, workaholism is a state that damages both the members of the profession and the organization for the occupation of policing, as in every occupational group. In this regard, it is a favorable situation that the findings obtained in this research are not sufficient.

\section{References}

Akın, U. \& Oğuz, E. (2010). Öğretmenlerin İşkoliklik ve Tükenmişlik Düzeylerinin İlişkisi ve Çeşitli Değişkenler Açısından Incelenmesi" Kuram ve Uygulamada Eğitim Yönetimi, Cilt 16, Sayı 3, s.309-327

Aziz, S. ve Cunningham, J. (2008). Workaholism, work stress, work-life imbalance: exploring gender's role" Gender in Management: An International Journal Vol. 23 No. 8, pp. 553-556

Azizoğlu, Ö. \& Özyer, K. (2010). Polislerde Tükenmişlik Sendromu Üzerine Bir Ampirik Çalışma, Anatolia Turizm Araştırmaları Dergisi,(Prof. Dr. Hasan Işın Definer Özel sayısı 21.1 pp. 137-147.

Bardakçı, S. (2007). Eğitim Yöneticilerinin İnternet Kullanımına İlişkin Tutumlarının İşkoliklik Eğilimleri Üzerine Etkilerinin Belirlenmesi" Gazi Osman Paşa Üniversitesi Sosyal Bilimler Enstitüsü, Yayımlanmamış Yüksek Lisans Tezi, 2007

Bashan, E. (2012). İşkoliklik ve Tükenmişlik Arasındaki Iliş̧kiyi Ölçmeye Yönelik Bir Araştırma, Dumlupınar Üniversitesi, Sosyal Bilimler Enstitüsü, Yayımlanmamış Yüksek Lisans Tezi, Kütahya

Bayraktaroğlu, S. Kutaniş, R.Ö. \& Dosaliyeva, D. (2009). İşkoliklik ve Örgütsel Bağlılık: Bankacılık Sektöründe Karşılaştırmalı Bir Araştırma, 17. Ulusal Yönetim ve Organizasyon Kongresi 21-23 Mayıs 2009 Eskişehir Osmangazi Üniversitesi, Bildiriler Kitabı, s.553-558

Burke, R. J. (2000). Workaholism in organizations: psychological and physical wellbeing consequences, Stress Medicine, 16, p 11-16,

Burke, R., J. Koyuncu, M., \& Fiksenbaum, L. (2007). Workaholism, Work And Extra-Work Satisfactions, And Psychological Well-Being Among Professors In Turkey, İ̧̧,Güç The Journal of Industrial Relations Human Resources 9 (1), http://www.isgucdergi.org/pdf/ronaldmustafa.pdf, 2007

Chamberlin, C.M. \& Zhang, N. (2009) "Workaholism, Health, and Self-Acceptance" Journal of Counseling \& Development v.87, p.159-169

Delice, M. \& Günbeyi M. (2013). Duygusal Zeka ve Liderlik ilişkisinin Incelenmesi: Polis Teşkilatı Örneği. İktisadi ve İdari Bilimler Dergisi/Journal of Ecomomics and Administrative Sciences, 27.1 Dewilde, T., Dewettinck, K. \& Vos, A. D. (2007). When Work Becomes an Addiction: An Exploration Of Individual And Organizational Antecetends of Workaholism and Impaction Employee Outcomes, Vlerick Leuven Gent Working Paper Series 2007/33 p.1-22

Doğan, T. \& Fatma D. T. (2011). Duwas İşkoliklik Ölçeği Türkçe Formunun (DUWASTR) Geçerlik ve Güvenirliğinin İncelenmesi, Abant İzzet Baysal Üniversitesi Eğitim Fakültesi Dergisi 
Douglas, J. E. ve Robyn J. M. (2006). Workaholic or Just Hard Worker?", Career Development International, Vol. 11, No. 5, p. 394-417

Emhan, A., Mete M. \& Emhan A. (2012). Kamu ve Özel Sektör Çalışanlarında İşkoliklik ve Obsesyon Arasındaki İlişkinin İncelenmesi, Dicle Tıp Dergisi pp.75-79

Günbeyi, M. \& Gündoğdu, T. (2010). Polis Teşkilatının “iş̧kolik Çalışanları” Doğuş Üniversitesi Dergisi, 11 (1) s.56-63,

Huang, J.C., Hu, C. ve Wu, T.C. (2010). Psychometric Properties of the Chinese Version of the Workaholism Battery" The Journal of Psychology, 144 (2), p.163-183

Hutcheson, G. \& Sofroniou, N. (1999). The Multivariate Social Scientist: Introductory statistic using generalized linear models. Sage Publications, London.

Karagöz Y., Çatı K. \& Koçoğlu, C.M. (2010). Cep Telefonu Ve Operatör Tercihinde Etkili Olabilecek Faktörlerin Demografik Özelliklere Bağlı Olarak İrdelenmesi, Dumlupınar Üniversitesi Sosyal Bilimler Dergisi , Cilt Sayı 23, s.7-24

Kart, M., E. (2005). Reability and Validity of The Workaholism Battery (Work-Bat): Turkish Form, Social Behavior and Personality, 33 (6), s. 609-618

Kaya, O.Ş. (2010). Ankara illinde Çalışan Polislerin Tükenmişlik Düzeylerinin Bazı Değişkenler Açısından İncelenmesi, Yayımlanmamış Yüksek Lisans Tezi, Çukurova Üniversitesi, Sosyal Bilimler Enstitüsü, Adana

McMillan, L. HW, et al. (2001). Understanding workaholism: Data synthesis, theoretical critique, and future design strategies." International Journal of Stress Management 8.2 p.69-91.

Porter, G. (1996).Organizational impact of workaholism: suggestions for researching the negative outcomes of excessive work" Journal of Occupational Health Psychology, 1, p.70-84

Schaufeli, W. B., Toon W. Taris, \& Arnold B. B. (2008). It takes two to tango. Workaholism is working excessively and working compulsively. The long work hours culture. Causes, consequences and choices pp. 203-226.

Seybold, C.K. \& Salomone, P.,R. (1994). Understanding workaholism: a review of causes and counseling approaches", Journal of Counseling \& Development, 73, p. 4-9

Spence, J., T. \& Robbins, A. S. (1992). Workaholism: definition, measurement and preliminary results, Journal of Personality Assessment, 58, p. 160-178.

Şişman, Y. \& Topgül, S. (2013). Polislerin İş ve Aile Yaşamı Arasında Dengenin Sağlanmasına İlişkin Görüşleri: Eskişehir II Merkezinde Görevli Polisler Üzerine Bir Araştırma, Tunceli Üniversitesi Sosyal Bilimler Dergisi Cilt 1, Sayı 2, Bahar 2013

Tiftik, H. (2014). Burnout Research On Junior Administrative Police Officers In The Police Department, Unpublished Paper

Tonta, Y., (2008). Faktör Analizi Sunusu, http://yunus.hacettepe. edu.tr/ tonta /courses/spring2008/bby208-12-faktör-analizi.ppt (Son erişim tarihi:20.07.2009)

Yöney, H. (2007). Hayat Çalışmaktan ibaret Mi? 12 Ocak, 2007, http://www.herbikonu.com/haberci/haber_oku.asp?haber=71

Zincirkıran, M. (2013). İşkoliklik İle İş-Aile Çatışması İlişkisinin Yapısal Eşitlik Modeli İle Incelenmesi: Sağlık İşletmelerinde Bir Uygulama, Yayımlanmamış Doktora Tezi, Dicle Üniversitesi, Sosyal Bilimler Enstitüsü, Diyarbakır 